\title{
REPRESENTASI SOSIAL TENTANG MAKNA MALU PADA GENERASI MUDA DI JAKARTA
}

\author{
E. Constant Giawa, Nani Nurrachman \\ Fakultas Psikologi, Universitas Katolik Indonesia Atma Jaya \\ J1. Jendral Sudirman No.51, Setiabudi, Jakarta Selatan, Daerah Khusus Ibukota Jakarta 12930 \\ constantg36@gmail.com
}

\begin{abstract}
This study aims to find out the meaning of shame in the young generation of Jakarta. Shame as one of the basic emotions, continues to evolve according to the age level and social changes that occur. The theory used is social representation theory with approach of social representation structure that will find central core and peripheral element of shame. This study used mixed method design: quantitative method with hierarchized evocation technique and qualitative method by conducting interview. The hierarchized evocation technique was performed on 252 participants using a questionnaire. While interviews were conducted on 13 participants which explore further about the shame. Participants were obtained by using snowball and accidental sampling technique, with the criteria as followed: students, at least fifth semester and maximum age is 25 . The results show that the meaning of shame in Jakarta young generation is related to self-doubt, events that lead to negative judgment, unideal physical appearance, violation of moral principles and mismatch on etiquette. These five attributes are very strongly attached to the collective memory of the younger generation.
\end{abstract}

Keywords: shame; young generation; social representation

\begin{abstract}
Abstrak
Penelitian ini bertujuan untuk mengetahui gambaran makna malu pada generasi muda di Jakarta. Malu sebagai salah satu dari emosi dasar, terus berkembang sesuai dengan tingkatan usia dan perubahan sosial yang terjadi. Teori yang digunakan adalah teori representasi sosial dengan pendekatan struktur representasi sosial yang akan menemukan central core dan peripheral element dari malu. Penelitian menggunakan desain mixed method yaitu, metode kuantitatif dengan teknik hierarchized evocation dan metode kualitatif dengan melakukan wawancara. Teknik hierarchized evocation dilakukan pada 252 partisipan dengan menggunakan kuesioner. Sedangkan wawancara dilakukan pada 13 partisipan yang menggali lebih jauh mengenai rasa malu. Partisipan diperoleh dengan menggunakan teknik snowball dan accidental sampling dengan kriteria yaitu, mahasiswa minimal semester lima dan usia maksimal adalah 25 tahun. Hasil penelitian menunjukkan pemaknaan rasa malu pada generasi muda di Jakarta berkaitan dengan ketidakyakinan pada diri sendiri, peristiwa yang menimbulkan penilaian negatif, tampilan fisik yang tak ideal, pelanggaran prinsip moralitas dan ketidaksesuaian pada etiket. Kelima atribut ini sangat kuat melekat pada memori kolektif generasi muda.
\end{abstract}

Kata kunci: malu; generasi muda; representasi sosial

\section{PENDAHULUAN}

Sejak kecil seseorang diajarkan untuk memiliki rasa malu, seperti malu berbuat yang tidak baik, tidak sopan dan tidak sesuai dengan norma yang berlaku di lingkungannya. Pengertian kata malu menunjukkan bahwa malu erat kaitannya dengan etika dan moralitas. Bertens (2007) mengatakan bahwa etika sebagai salah satu bagian dari filsafat, mempertanyakan tentang apa yang harus dan tidak boleh dilakukan dan mempersoalkan yang baik dan buruk untuk dilakukan. Bertens (2007) selanjutnya menjelaskan bahwa etika merupakan refleksi kritis dan rasional tentang nilai, ajaran dan pandangan-pandangan moral. Moralitas yang dimaksud merupakan ajaran atau nilai yang berlaku di masyarakat yang bisa bersumber dari akal sehat, hukum, agama, kebiasaan dan 
juga hati nurani. Pada kajian antropologi, pemahaman manusia tentang rasa malu yang muncul sebagai akibat dari tindakan yang memalukan, secara turun-temurun diwariskan dari satu generasi ke generasi berikutnya. Benedict (1959) menyebutkan bahwa komunitas yang menjunjung tinggi moralitas sebagai inti dari kebudayaan, cenderung lebih tinggi budaya malunya, sehingga jika terjadi pelanggaran sosial yang menyimpang dari norma sosial maka rasa malu menjadi sanksi sosial yang tepat.

Pada beberapa studi psikologi disebutkan bahwa perasaan malu berkaitan dengan kekesalan yang muncul karena adanya perasaan tidak mampu (Wells \& Jones, 2000), merasa diri hina (Adams \& Robinson, 2001), perasaan tidak berdaya dan kegagalan pribadi (Wilson, 2000), tidak berguna (Wiklander, Samuelsson \& Asberg, 2003) dan perasaan rendah diri (Wright \& Gudjonsson, 2007). Menurut Kim (2010), perasaan-perasaan yang berkaitan dengan rasa malu tersebut dapat dikelompokkan ke dalam tiga pembagian yang menyangkut kebermanfaatan diri, prestasi pribadi dan sikap diri.

Rasa malu memicu seseorang memodifikasi perilakunya agar mudah menyesuaikan diri dengan lingkungan. Malu menjadi salah satu faktor penentu perilaku sosial (Fessler, 2004). Seseorang berupaya untuk berperilaku sesuai dengan nilai atau norma yang telah menjadi kesepakatan bersama. Nilai atau norma ini dijadikan sebagai parameter bertingkah laku, apakah itu benar atau salah, tepat atau tidak tepat dan sesuai atau tidak sesuai. Arti-nya, malu merupakan emosi psikologis yang mencerminkan konteks sosial yaitu norma-norma sosial (Kim, 2010). Merujuk pada konteks sosial ini maka rasa malu akan memotivasi individu untuk membatalkan perilaku yang tidak sesuai dengan norma kelompoknya (Gausel, 2012).

Perilaku yang baik dan tepat yang bersesuaian dengan norma atau aturan yang berlaku, merupakan hasil akhir yang diharap- kan sebagai dampak dari hadirnya rasa malu. Seseorang yang secara hukum su-dah dinyatakan bersalah dan sedang men-jalani proses hukumannya dalam beberapa kasus justru tidak merasa malu dengan peristiwa yang terjadi pada dirinya. Rasa malu yang dianggap bisa menjadi sanksi sosial bagi seseorang ketika melakukan tindakan yang memalukan justru tidak efektif memberikan efek jera. Pelanggaran demi pelanggaran terhadap norma sosial terus saja berlangsung dan bertambah banyak. Dari berbagai keadaan ini maka menjadi wajar jika kekhawatiran akan lunturnya budaya malu di dalam kehidupan masyarakat Indonesia semakin kuat.

Fenomena tersebut juga bisa dilihat pada kelompok generasi muda. Generasi muda yang diharapkan sebagai tulang punggung bangsa dan penerus kepemimpinan justru ikut dikahwatirkan mengalami kemunduran dalam memelihara budaya malu. Generasi muda atau pemuda tak bisa dilepaskan dari kelompok mahasiswa sebagai salah satu elemen penting di dalamnya. Mahasiswa adalah bagian dari generasi muda yang merupakan kaum elite intelektual dengan tanggung jawab tertentu. Mahasiswa berada pada tataran elite sesuai dengan kelebihan yang dimiliki, dengan kekhasan fungsi, peran dan tanggung jawab yang diembannya seperti tanggung jawab intelektual, sosial dan tanggung jawab moral.

Pada rentang usia mahasiswa, tugas-tugas perkembangan yang berkaitan dengan etika dan moral semestinya sudah dipahami. Hurlock (2003) menyebutkan bahwa ada sejumlah tugas perkembangan manusia di masa akhir remaja yang berhubungan dengan kehidupan sosialnya di saat menjadi mahasiswa. Tugas tersebut antara lain pencapaian pola hubungan baru dengan teman yang lebih matang sesuai dengan keyakinan dan etika moral yang berlaku di masyarakat, mencapai peran sosial yang selaras dengan tuntutan sosial dan kultur masyarakat, mencapai tingkah laku sosial tertentu dan memperoleh seperangkat nilai 
dan sistem etika sebagai pedoman bertingkah laku.

Perilaku generasi muda dalam menggunakan media sosial belakangan ini dinilai telah jauh menyimpang dari yang semestinya. Media sosial kini menjadi sarana untuk membentuk citra diri dan identitas yang baru (Prasetya, 2016). Berbagai perubahan sosial juga terjadi di kalangan generasi muda sebagai pengguna utama dari media sosial, khususnya fasilitas jejaring sosial. Perubahan tersebut mencakup perubahan dalam bahasa, kosakata, gaya hidup hingga tataran pola pikir dan konstruksi gagasan. Perubahan dalam penggunaan bahasa dan kosakata ini sering membuat generasi yang lebih tua beranggapan bahwa generasi muda tidak memiliki etika dalam berbahasa atau berkomunikasi. Demikian juga dalam perubahan gaya hidup, hal-hal yang dulu dianggap sakral karena memiliki muatan nilai dan norma sosial yang tinggi kini seakan tertabrak dan mengalami pergeseran makna. Hal ini bisa diamati dengan melihat materi-materi yang dipublikasikan di media sosial. Tidak jarang para generasi muda berani menampilkan foto-foto pribadi yang sepantasnya hanya dipublikasikan di ruang pribadi. Hal-hal yang semestinya tidak dilihat orang lain justru kini menjadi sesuatu yang lazim untuk diperlihatkan. Generasi muda sepertinya hidup di era yang tidak perlu memerhatikan etika. Perilaku dari sekelompok generasi muda tersebut sangat bertolak belakang dengan nilai-nilai sosial yang berlaku di masyarakat. Generasi muda yang diharapkan menjadi tonggak perubahan bangsa, justru berkontribusi melakukan perilaku-perilaku yang memalukan.

Interaksi sosial yang terjadi antara generasi muda dengan lingkungan sosialnya tanpa disadari telah membangun konstruksi makna tentang rasa malu berdasarkan pemahaman sendiri. Pemaknaan tersebut merupakan representasi sosial generasi muda. Sistem nilai, kebiasaan, gagasan atau konsep berasal dari pengalaman hidup yang terus berkembang karena terjalinnya komunikasi yang berkesinambungan di antara anggota masyarakat. Proses komunikasi ini juga sangat dipengaruhi oleh sejarah dan konteks dari objek yang diamati. Menurut Moscovici (dalam Ferdinand, 2010), makna diciptakan dari suatu sistim melalui negosiasi sosial dan bukan sesuatu yang baku atau telah ditentukan terlebih dahulu. Pendekatan ini dalam psikologi sosial dikenal sebagai representasi sosial, Pendekatan yang hendak memberi gambaran bagaimana suatu konsep atau gagasan dipahami, diyakini dan dijalankan oleh suatu kelompok sosial (Moscovici, dalam Ferdinand, 2010).

Moscovici (1984) menyebutkan bahwa representasi sosial membuka kemungkinan untuk mempersoalkan hal yang paling mendasar di dalam pemikiran ilmu sosial yaitu kebenaran. Kebenaran tidak pernah berwajah dan bersifat tunggal. Setiap tempat dengan konteks budaya dan sejarah yang berbeda akan mendefenisikan kebenaran yang berbeda pula. Masih menurut Moscovici (1984), representasi sosial memberikan pengetahuan yang mendasar untuk memahami posisi masyarakat biasa dalam menghadapi situasi yang beraneka ragam sesuai dengan sudut pandang masing-masing. Untuk itu maka budaya, sejarah, kebiasaan, praktek linguistik dan emosi yang terabaikan pada pengetahuan ilmiah dalam masyarakat modern, justru dalam representasi sosial dianggap sebagai elemen dasar yang membentuk struktur pemikiran masyarakat (Permanadeli, 2011).

Berangkat dari uraian di atas maka penelitian ini hendak melihat gambaran representasi sosial tentang rasa malu pada generasi muda Jakarta. Mahasiswa dipilih sebagai sampel penelitian atas dasar keberadaan kelompok ini sebagai kelompok elit intelektual yang mampu berpikir secara kritis dalam mengemban peran mereka sebagai kekuatan moral bangsa dan Negara. Dengan menggunakan pendekatan structural, central core dan elemen peripheral dari rasa malu dapat diidentifikasi.

Central core akan menunjukkan gagasan apa yang dianggap lebih penting, paling melekat 
kuat, esensial dan cenderung bersifat menetap dari rasa malu. Sementara elemen peripheral akan memberikan gambaran yang bersifat dinamis dan bisa berubah. Rasa malu yang dipahami, diyakini dan dijalankan oleh generasi muda diharapkan akan menjembatani kesenjangan pemahaman masyarakat dengan generasi muda. Konsep rasa malu yang direpresentasikan oleh generasi muda akan membantu kita untuk memahami struktur pemikiran mereka mengenai konsep tersebut. Dengan memahami kelompok ini maka diharapkan akan ditemukan pendekatan yang tepat agar generasi muda di Indonesia tetap bisa menjadi penerus dan pewaris bangsa.

\section{METODE}

Penelitian ini menggunakan pendekatan mixed method yang terdiri dari pendekatan kuantitatif dan pendekatan kualitatif. Penelitian ini menggunakan non random probability sampling dengan metode snowball sampling dan accidental sampling. Sejumlah kriteria telah ditentukan seperti masa kuliah setidaknya sedang menempuh semester lima dengan usia maksimal 25 tahun. Subjek didapatkan dari 9 perguruan tinggi yang ada di Jakarta. Terdapat 252 orang yang menjadi partisipan untuk mengisi kuesioner dan 13 orang yang menjadi partisipan wawancara. Jakarta yang merupakan etalase Indonesia diasumsikan bisa merepresentasikan keberagaman masyarakat Indonesia. Hal ni didukung dengan keberagaman suku bangsa dari para partisipan dimana partisipan berasal dari 12 suku bangsa di Indonesia. Suku bangsa tersebut adalah Jawa, Tionghoa, Batak, Sunda, Flores, Ambon, Minang, Betawi, Melayu, Bugis, Minahasa dan Nias.

Pendekatan kuantitatif dimaksudkan untuk mendapatkan atribut dan struktur berupa central core dan element peripheral dari representasi sosial tentang rasa malu dengan metoda Hierarchized Evocation (Kmiec \& Roland-Lévy, 2013). Pada metode hierarchized evocation partisipan penelitian berjumlah 252 orang. Partisipan diminta menuliskan sejumlah hal yang terpikirkan ketika mendengar kata "malu". Respons tersebut kemudian diranking oleh Partisipan sesuai derajat kepentingannya.

Data yang diperoleh dengan menggunakan metode hierarchized evocation dapat dianalisis dengan tahapan, (1) analisis leksikal dan kategorisasi dari atribut-atribut yang muncul. Pada tahapan ini atribut-atribut yang secara semantik sama akan dikategorisasikan pada kategori yang sama lalu dihitung frekuensinya, (2) olah statistik dengan menghitung persentase dari frekuensi kemunculan atribut yang telah dikategorisasikan. Hasil dari perhitungan persentase frekuensi ini disertai dengan urutan derajat kepentingan atau ranking, dijadikan sebagai acuan untuk menentukan central core dan element peripheral representasi sosial dari "malu". Respon yang sering muncul serta mendapat urutan tertinggi dalam derajat kepentingan adalah central core dari representasi sosial, sedangkan respon yang jarang muncul namun mendapat urutan tertinggi dalam derajat kepentingan adalah elemen peripheral, termasuk di dalamnya respon yang sering muncul namun mendapat ranking yang rendah.

Pendekatan kualitatif yang dilakukan menggunakan metoda wawancara yang bertujuan untuk memperdalam pengertian dari central core dan element peripheral yang didapatkan dari metoda kuantitatif yang sebelumnya telah dilakukan. Wawancara ini juga ditujukan untuk mendapatkan gambaran tentang batasan-batasan perilaku yang memalukan sesuai dengan pemahaman dan keyakinan partisipan. Data yang didapatkan dari 13 partisipan dianalisis melalui beberapa tahapan,, (1) membuat verbatim dari hasil wawancara, (2) memilih data yang relevan dengan permasalahan, (3) membuat tabel coding, (4) membandingkan hasil antar partisipan dan, (5) memaparkan hasil temuan berupa data pendukung untuk menjelaskan struktur representasi sosial yang diteliti. 


\section{HASIL DAN PEMBAHASAN}

Berdasarkan hasil perhitungan persentase frekuensi kemunculan dan nilai rata-rata ranking yang diperoleh, maka dapat dipetakan central core dan element peripheral dari representasi sosial dari malu. Pemetaan ini didasarkan pada ketentuan dimana batas minimal persentase frekuensi adalah $20 \%$ yang artinya ada minimal $20 \%$ dari 252 orang partisipan yang meyakini bahwa atribut yang dimaksud berhubungan atau ada keterkaitannya dengan malu. Jika nilai persentasenya sama atau lebih besar dari $20 \%$ maka persentase tersebut dikategorikan pada kategori frekuensi tinggi.

Untuk menentukan ranking tiap atribut maka angka 3.50 dijadikan sebagai cut-off. Dengan demikian maka hasil dari nilai rata-rata ranking dari tiap atribut akan menentukan kategori ranking dari atribut tersebut, apakah termasuk pada high ranking atau pada low ranking. Semakin tinggi ranking dari atribut yang diberikan maka partisipan menganggap bahwa atribut tersebut semakin penting.

Tabel 1 memberikan gambaran mengenai central core dan element peripheral yang penentuannya mengacu pada ketentuan di atas.

\section{Tabel 1.}

Central Core dan Peripheral

Representasi Sosial tentang Malu pada Generasi Muda

\begin{tabular}{|c|c|c|}
\hline & $\begin{array}{c}\text { High Rank } \\
(1-3.5) \\
\text { Central core }\end{array}$ & $\begin{array}{c}\text { Low Rank } \\
\text { (3.5-7) } \\
\text { Peripheral }\end{array}$ \\
\hline $\begin{array}{l}\text { High } \\
\text { Frequency } \\
(>20 \%)\end{array}$ & $\begin{array}{l}\text { 1. Tidak yakin } \\
\text { pada diri } \\
\text { sendiri } 53,57 \% \text {; } \\
2,58 \\
\text { 2. Peristiwa yang } \\
\text { memunculkan } \\
\text { penilaian } \\
\text { negatif 46,82\%; } \\
\text { 2,86 } \\
\text { 3. Tampilan fisik } \\
\text { yang tak ideal } \\
\text { 40,07\%; } 2,97 \\
\text { 4. Moralitas } \\
\text { 35,71\%; } 2,76 \\
\text { 5. Etiket 35,31\%; } \\
\text { 2,89 }\end{array}$ & $\begin{array}{l}\text { 1. Prestasi rendah } \\
\text { 40,87\%; 3,69 } \\
\text { 2. Ketidakdisiplina } \\
\text { n 34,92\%; 4,19 } \\
\text { 3. Melakukan } \\
\text { kesalahan } \\
\text { 31,74\%; 3,57 } \\
\text { 4. } \text { Tidak aktif dan } \\
\text { berinisiatif } \\
\text { 19,81\%; 3,54 }\end{array}$ \\
\hline
\end{tabular}

Dari Tabel 1 dapat dilihat bahwa central core dari makna malu pada generasi muda di Jakarta secara berurutan berkaitan dengan persoalan ketidakyakinan pada diri sendiri, peristiwa yang menimbulkan penilaian negatif dari orang lain, tampilan fisik yang tak ideal, pelanggaran prinsip-prinsip moralitas dan ketidaksesuaian pada prinsip etika. Kelima central core tersebut dipahami, dan diyakini sebagai kondisi atau situasi yang bisa membuat generasi muda merasa malu. Kelima atribut ini muncul sebagai komponen inti central core yang merupakan struktur representasi sosial dari rasa malu. Atribut central core tersebut bersifat stabil, koheren dan diyakini. Kemunculannya tidak terlepas dari pengaruh faktor historis, ideologis dan sosiologis. Dalam pendekatan representasi sosial, apa yang dipahami, diyakini dan dijalankan oleh generasi muda berkaitan dengan pemaknaan mereka tentang malu, bisa saja berbeda dengan teori dan pandangan yang sudah ada sebelumnya.

Selain menemukan lima central core, ditemukan juga empat atribut yang menjadi element peripheral. Keempat elemen tersebut adalah, prestasi yang rendah, ketidakdisiplinan, melakukan kesalahan, dan tidak aktif/berinisiatif. Elemen ini bersifat dinamis, masih bisa berubah-ubah sesuai dengan konteks dimana rasa malu tersebut ditempatkan.

Rasa malu pada hakikatnya berkaitan erat dengan kebutuhan manusia untuk menutupi apa yang tersingkap. Merasa malu berarti merasa terlihat oleh orang lain. Malu hadir ketika seseorang dievaluasi oleh lingkungan terdekat dan di dalam penilaian tersebut seseorang merasa tidak menampilkan standar diri dan nilai-nilai ideal di lingkungannya. Gilbert dan Irons (2009) menegaskan bahwa emosi rasa malu berkaitan dengan sering munculnya evaluasi diri di saat lingkungan sosial bertentangan dengan perilaku yang ditampilkan, berkaitan dengan keterbatasan sumber daya serta berkaitan dengan tidak kuatnya perilaku saling mendukung dan peduli di antara anggota kelompok sosial. 
Dari perspektif ideologis, malu menjadi suatu sistem nilai yang dijadikan sebagai panduan berperilaku. Rasa malu mengarahkan individu untuk mempertanyakan tentang apa yang harus dan tidak boleh dilakukan dan mempersoalkan yang baik dan buruk untuk dilakukan. Perilaku yang melanggar nilai kesopanan, kesusilaan atau keluar dari prinsipprinsip moralitas akan menyebabkan seseorang menjadi malu. Sedangkan dari perspektif sosiologis, rasa malu pada generasi muda berkaitan dengan interaksi sosial yang terjadi dengan lingkungan sekitar. Mereka menjadi malu jika mereka tidak mampu menyesuaikan diri dengan lingkungannya lalu diliputi oleh kekesalan yang muncul karena adanya perasaan tidak mampu, tidak berdaya, tidak berguna dan perasaan rendah diri. Rasa malu berfokus pada hadirnya perbandingan sosial dan pengenalan akan lingkungan sosial dari seseorang (Gilbert dan Irons, 2009). Faktor sosiologis ini berperan untuk membentuk pola interaksi yang terjadi di antara generasi muda. Yang selalu disesuaikan dengan tingkat kematangan individu berdasarkan batasan usianya.

Ditinjau dari perspektif historis, mengemukanya tiga central core struktur representasi sosial rasa malu, sesuai dengan urutan kemunculannya yaitu ketidakyakinan pada diri sendiri, peristiwa yang menimbulkan penilaian negatif dari orang lain serta tampilan fisik yang tak ideal, menunjukkan telah terjadinya pergeseran dari pemaknaan rasa malu pada generasi muda. Lebih jauh jika ditelaah, maka ketiga central core tersebut berkaitan dengan situasi yang mempersyaratkan kehadiran orang lain yang melakukan penilaian. Hasil penelitian Sumartani dkk. (2016) menyatakan bahwa situasi akan memunculkan rasa malu apabila melibatkan kehadiran orang lain saat suatu peristiwa terjadi. Lebih lanjut penelitian Anggarasari dan Kumolohadi (2012) menyatakan bahwa rasa malu diartikan sebagai tanda harga diri, karena seseorang dapat dikatakan memiliki harga diri apabila dia memiliki rasa malu. Rasa malu merupakan sesuatu yang sehat karena dapat mendorong seseorang untuk menjaga sikap dan harga dirinya.

Sejarah mencatat bahwa di masa lalu Generasi muda lebih memberikan prioritas pada persoalan-persoalan kepemimpinan bangsa dan moralitas. Hal ini tidak terlepas dari keadaan dan situasi bangsa di masa itu. Fakta bahwa Indonesia berada di bawah penjajahan bangsa lain menggerakkan perjuangan generasi muda untuk merdeka. Generasi muda merasa malu menjadi bagian dari masyarakat terjajah.

Menilik sisi historis, berdirinya Budi Utomo di tahun 1908 menjadi momen awal kebangkitan generasi muda untuk mempersatukan diri. Rasa persatuan tersebut diperkuat lagi dengan lahirnya Sumpah Pemuda di tahun 1928 di Jakarta. Segala perbedaan di antara generasi muda di masa itu dipersatukan di bawah ikatan persatuan bernama Indonesia (Poesponegoro, 2008). Perjuangan generasi muda tidak berhenti sampai di situ karena generasi muda memiliki peran pada masa proklamasi kemerdekaan dan setelah kemerdekaan pergerakan generasi muda terus berlangsung. Perjuangan terarah pada usaha mempertahankan dan mengisi kemerdekaan. Generasi muda tampil sebagai pengontrol jalannnya pembangunan dan keberlangsungan proses demokrasi.

Generasi muda di masa lalu menjadi generasi yang lebih peka, peduli dengan lingkungan sosial, bersikap kritis dengan solusi yang ditawarkan, aktif dan mengedepankan kepantasan bertingkah laku yang bersandar pada nilai-nilai etika. Generasi muda juga mengedepankan keinginan untuk meraih prestasi maksimal dengan sikap disiplin dan aktif untuk berpertisipasi dalam kehidupan bermasyarakat.

Saat ini pergeseran itu telah terjadi, rasa malu lebih kuat muncul di saat generasi muda merasa tidak yakin dengan diri sendiri, muncul saat ada kejadian tertentu yang akan membuat orang lain menilai negatif dirinya 
serta muncul saat generasi muda merasa bahwa tampilan fisiknya tak seideal yang ia inginkan.

Kondisi masa lalu di saat berlangsungnya penjajahan juga berpengaruh terhadap terbentuknya mental rendah diri sebagai bangsa yang terjajah. Tercatat di masa penjajahan, tidak semua generasi muda bisa berkesempatan untuk melanjutkan studi ke jenjang tertentu yang lebih tinggi. Pembedaan atau pengkategorisasian kelompok masyarakat menjadi pertimbangan bagi seseorang untuk bersekolah lebih tinggi. Akibatnya, hanya golongan ekonomi atas atau kerabat para penjajah yang berkesempatan untuk mengenyam pendidikan. Hal ini berlangsung dalam kurun waktu yang cukup lama dan ikut memengaruhi pola pikir generasi muda.

Generasi muda saat ini lebih dituntut untuk memiliki kompetensi akademik yang tinggi dengan mengabaikan kompetensi sosial yang sebenarnya sangat diperlukan ketika lulus dari sekolah. Perkembangan pesat di bidang teknologi informasi juga berkontribusi membentuk budaya baru di kalangan generasi muda. Saat ini generasi muda seakan berada di dunianya sendiri dengan berbagai fasilitas. Mereka memiliki jejaring sosial di mana media ini tidak hanya memudahkan untuk berkomunikasi namun dimanfaatkan untuk membangun citra diri dan identitas baru. Berbagai perubahan terjadi, khususnya dalam pemakaian bahasa dan kosa kata. Bermunculanlah istilah baru yang hanya dimengerti oleh komunitas mereka sendiri. Gaya hidup juga bergeser. Hal-hal yang dulu dianggap sakral kini seakan tertabrak oleh generasi muda tersebut. Etika berperilaku tidak lagi menjadi sesuatu yang perlu dipertimbangkan saat bersosialisasi dengan orang lain. Hiruk pikuk politik juga berkontribusi bagi munculnya generasi muda yang apatis. Situasi politik yang serba tidak pasti dan tidak kondusif menjadi stimulus yang membuat generasi muda tidak begitu peduli dengan apa yang terjadi di sekitar. Tontonan politik yang tidak santun yang ditunjukkan oleh segelintir elite politik membuat generasi muda apatis terhadap berbagai perhelatan politik. Ini bisa dilihat dari tingkat partisipasi generasi muda di saat terjadinya pemilihan legislatif, kepala daerah maupun presiden. Lambatnya pertumbuhan ekonomi, juga berperan mmembentuk untuk lebih berkonsentrasi mencari materi. Melihat sejumlah kondisi yang terjadi tersebut maka pergeseran demi pergeseran akan terus berlangsung sesuai dengan perubahan sosial masyarakat. Kalau dulu generasi muda mementingkan persoalan kepemimpinan bangsa dan moralitas maka kini prioritas tersebut telah tergantikan dengan atribut yang lebih berfokus pada keadaan diri generasi muda itu sendiri.

Generasi muda menyadari hal tersebut. Mereka mengakui bahwa derajat kepentingan dari atribut ketidakyakinan diri, penilaian negatif dan tampilan fisik yang tak ideal jauh lebih penting dibanding dengan pelanggaran prinsip moralitas dan etika bertingkah laku. Hal ini bisa terlihat dari keurutan central core yang didapatkan. Hadirnya rasa malu karena adanya keinginan untuk membandingkan diri dengan orang lain sehingga memunculkan ketidakpuasan pada kemampuan untuk menyesuaikan diri yang pada akhirnya membuat seseorang mengembangkan sikap untuk menolak diri sendiri (Sumartani dkk., 2016).

Generasi muda tidak membantah jika ada pandangan masyarakat bahwa generasi muda sekarang dianggap sebagai generasi muda yang tidak tahu malu atau generasi yang memalukan. Walau hal itu tidak bisa begitu saja digeneralisir namun generasi juga sekaligus melihat fakta bahwa generasi muda saat ini memang mengalami pergeseran dalam mewujudnyatakan rasa malu tersebut. Menjadi tidak mengherankan ketika generasi muda saat ini lebih merasa malu jika pakaian yang dikenakan tidak bagus, terlihat gemuk atau jerawatan, melakukan presentasi atau berbicara di depan umum, ditegur di depan orang lain, merasa tidak mampu melakukan sesuatu dan sejumlah contoh lainnya 
dibanding merasa malu karena melanggar peraturan lalu lintas, berbicara tidak sopan, tidak menghargai dosen, membuang sampah sembarangan atau tidak peduli dengan lingkungan sekitar. Artinya, di kalangan generasi muda, beberapa contoh perilaku di atas menjadi wujud dari makna rasa malu di dalam kehidupan keseharian mereka yang dalam pendekatan representasi sosial menjadi wajar karena hal-hal tersebutlah yang menjadi pemahaman dan keyakinan mereka.

Pemaknaan generasi muda terhadap rasa malu juga ikut memberikan gambaran tentang batasan-batasan perilaku tertentu yang menurut mereka tidak memalukan atau bisa membuat mereka menjadi malu. Munculnya rasa malu dipahami oleh generasi muda sebagai akibat adanya perilaku yang menyimpang. Oleh karena itu seseorang berusaha untuk tidak menjadi malu karena terjadinya pelanggaran atau ketidaksesuaian pada norma yang berlaku. Perasaan malu sangat penting dipupuk dalam masyarakat, karena rasa malu bisa menjadi benteng agar tidak melakukan sesuatu yang dianggap menyimpang dan melanggar norma-norma dalam masyarakat (Anggarasari dan Kumolohadi, 2012).

Pentingnya memiliki rasa malu terungkap dari argumentasi generasi muda bahwasanya rasa malu itu bisa memberikan batasanbatasan tertentu untuk mengatur kehidupan mereka. Rasa malu akan membuat mereka menjadi tahu diri, bisa menyesuaikan diri dengan lingkungan dan mengerti kepantasan dalam bertingkah laku. Argumentasi generasi muda ini menegaskan bahwa rasa malu bisa berfungsi untuk menetapkan batasan-batasan yang tepat untuk mencegah invasi atau penyerbuan yang melanggar kehormatan dan integritas orang lain. Dengan demikian maka malu menjadi salah satu faktor penentu perilaku sosial. Malu merupakan emosi psikologis yang mencerminkan konteks sosial yaitu norma-norma sosial sehingga memotivasi individu untuk membatalkan perilaku yang tidak sesuai dengan norma kelompoknya. Ini mengkonfirmasi hasil penelitian yang menyebutkan bahwa rasa malu memiliki karakteristik dan potensi yang berhubungan dengan perilaku anti sosial (Heaven, Ciarrochi, \& Leeson, 2009).

Beberapa keterbatasan dalam penelitian ini menyangkut pada persoalan metodologi. Seperti diketahui, dalam penelitian ini pendekatan struktural representasi sosial menjadi pilihan peneliti untuk memperoleh gambaran makna malu pada generasi muda. Melalui pendekatan sruktural ini bisa didapatkan atribut-atribut representasi sosial dari rasa malu, dan hal tersebut sudah terjawab sesuai dengan rumusan yang dibuat sebelumnya. Apabila di masa mendatang dilakukan penelitian serupa dengan menggunakan pendekatan dinamis maka akan diperoleh temuan lain yang menarik dan semakin memperkaya pengetahuan tentang gambaran rasa malu pada generasi muda di Jakarta. Persoalan reliabilitas pada pendekatan kuantitatif perlu lebih diperhatikan agar tidak terjebak dalam subjektivitas peneliti. Demikian juga dalam penyusunan panduan wawancara perlu lebih terdiferensiasi.

\section{SIMPULAN}

Generasi muda di Jakarta memaknai malu sebagai sesuatu yang dikaitkan dengan ketidakyakinan pada diri sendiri, peristiwa yang menimbulkan penilaian negatif dari orang lain, tampilan fisik yang tak ideal, pelanggaran pada prinsip-prinsip moralitas dan ketidaksesuaian pada etiket. Kelima hal tersebut dipahami, diyakini, dan dijalankan oleh generasi muda di Jakarta dalam memaknai rasa malu. Selain itu, ditemukan juga sejumlah makna lain, namun sifatnya masih berubah-ubah. Perubahan itu tergantung pada konteks sosial dimana generasi muda tersebut berada. Makna yang didapatkan ini berkaitan dengan prestasi yang rendah, ketidakdisiplinan, melakukan kesalahan, dan tidak aktif/berinisiatif. Hasil ini menunjukkan bahwa telah terjadi pergeseran makna rasa malu di kalangan generasi muda. Dulu generasi muda lebih 
memrioritaskan persoalan kepemimpinan dan moralitas dibandingkan dengan persoalan keyakinan pada diri sendiri, penilaian orang lain dan tampilan fisik yang ideal. Berbagai perubahan sosial yang terjadi menjadi penyebab terjadinya pergeseran tersebut. Hasil lain menunjukkan bahwa generasi muda di Jakarta memahami bahwa batasanbatasan perilaku yang memalukan adalah perilaku-perilaku yang tidak sesuai dengan prinsip-prinsip moralitas dan etiket.

\section{DAFTAR PUSTAKA}

Adams, K. M., \& Robinson, D. W. (2001). Shame reduction, affect regulation, and sexual boundary development: Essential building blocks of sexual addiction treatment. The Journal of Treatment \& Prevention, 8(1), 23-44. doi : 10.1080/10720160127559.

Anggarasari, N. H., \& Kumolohadi, R. R. A. (2012). Pelatihan komunikasi interpersonal untuk mengurangi rasa malu. Jurnal Intervensi Psikologi, 4 (1), 41-55. doi: 10.20885/intervensi psikologi.vol4.iss1.art3

Benedict, R. (1959). Patterns of culture. New York: Mentor Books.

Bertens, K. (2007). Etika. Jakarta: PT. Gramedia Pustaka Utama.

Ferdinand, P. (2010). Struktur dan kontradiksi pada representasi sosial tentang agama (Tesis tidak dipublikasikan). Depok. Fakultas Psikologi Universitas Indonesia.

Fessler, D. M. T. (2004). Shame in two cultures: Implications for evolutionary approaches. Journal of Cognition and Culture, 4(2), 207-262. doi: 10.1163/1568537041725097

Gausel, N. (2012). Facing in-group immorality: Differentiating expressed shame from expressed guilt. Review of European Studies, 4(4), 1-6. doi: 10.5539/res.v4n4p1

Gilbert, P., \& Irons, C. (2009). Shame, selfcriticism, and self-compassion in adolescence. London: Cambridge University Press.

Heaven, P. C. L., Ciarrochi, J., \& Leeson, P. (2009). The longitudinal links between shame and increasing hostility during adolescence. Personality and Individual Differences, 47(8), 841-844. doi: 10.1016/j.paid. 2009.07.002

Hurlock, E. B. (2003). Psikologi perkembangan, suatu pendekatan sepanjang rentang kehidupan. Jakarta. Penerbit Erlangga.

Kim, Y. (2010). An understanding of shame and guilt: Psycho-socio-spiritual meaning. Torch Trinity Journal, 13(2), 218-232.

Kmiec, R., \& Roland-Lévy, C. (2013). Social representations of risk and economics among young European citizens: A cross-cultural study. in $P$. Cunningham (ed.). Identities and citizenship education: Controversy, crisis and challenges (pp. 625 - 635). London: CiCe.

Moscovici, S. (1984). The phenomenon of social representations. In R.M. Farr \& S. Moscovici (Eds.), Social representations (pp. 3-69). Cambridge: Cambridge University Press.

Permanadeli, R. (2011). Social thinking and the production of local knowledge: Notes on a journey of social representation theory in Indonesia. Jakarta: Centre of Social Representation Studies.

Prasetya, A. B. (2016). Trend media sosial di kalangan remaja dalam perspektif 
budaya populer (disampaikan dalam Konferensi Comicos di Universitas Atmajaya). diunduh dari http://arifbudi.lecture.ub.ac.id/2016/0 7/

Poesponegoro, M. J. (2008). Sejarah nasional Indonesia. Jakarta: Balai Pustaka.

Sumartani, D. M., Dewi, T. A. A., Dewi, N. P. S., Natalya, N. P., Herdyanto, Y. K., Tobing, D. H., \& Dewi, A. A. S. (2016). Dinamika rasa malu paada remaja pubertas. Inquiry: Jurnal Ilmiah Psikologi, 7(2), 50-61.

Wells, M., \& Jones, R. (2000). Childhood parentification and shame proneness: A preliminary study. American Journal of Family Therapy, 28(1), 1927. doi: 10.1080/019261800261 789.
Wiklander, M., Samuelsson, M., \& Asberg, M. (2003). Shame reaction after suicide attempt. Scandinavian Journal of Caring Science, 17(3). doi: 10.1046/j.1471-6712.2003.00227.x

Wilson, M. (2000). Creativity and shame reduction in sex addiction treatment. Sexual addiction \& compulsivity: The Journal of Treatment \& Prevention, 7(4), 229-248, doi: 10.1080/1072016 0008403699

Wright, K., \& Gudjonsson, G. H. (2007). The development of a scale for meaning offence-related feelings of shame and guilt. The Journal of Forensic Psychiatry \& Psychology, 18(3), 307316. doi: 10.1080/14789940701292 810 